\title{
THE IMPRESSION OF PROFIT QUALITY AGAINST TIMELINESS IN FINANCIAL REPORTING
}

\author{
${ }^{123}$ Bambang Tri Wahyuono, Fetri Setyo Liyundira, Inud Danis Ikhwan Meranti \\ ${ }^{12}$ Departement of Accountinng, STIE Widya Gama Lumajang \\ ${ }^{3}$ STAI Darul Ulum BANYUWANGI \\ Email: liyundira90@gmail.com
}

\section{A R T I C L E IN F O}

Date of entry:

10 Oktober 2019

Revision Date:

24 November 2019

Date Received:

13 Desember 2019

\begin{abstract}
A B S T R A C T
The purpose of this study was to determine the effect of the profitability and size of the company on the timeliness of financial reporting of manufacturing companies listed on the Indonesia Stock Exchange for the period of 2016 - 2018. The data used in this study are secondary, in the form of company annual reports. The number of companies studied was 115 companies within a period of 3 years, resulting in 345 samples. This type of research is quantitative research. Where this study uses data collection methods and processes them then tested to describe the hypotheses that have been set. The selection of a sample is to use certain criteria. Data were analyzed using multiple linear regression. Based on the test results show that the profitability and size of the company significantly influence the timeliness. The test results showed that $7.1 \%$ of the variation in timeliness was explained by variations in the independent variables, namely ROA and SIZE. At the same time, the remaining $92.9 \%$ is explained by other variables not included in this research model.
\end{abstract}

Keywords: Profitability, Company Size, Timeliness.

Cite this as: Wahyuono, B. T, Liyundira, F. S., Meranti, I. D. I. (2020). THE IMPRESSION OF PROFIT QUALITY AGAINST TIMELINESS IN FINANCIAL REPORTING. Assets : Jurnal Ilmiah Ilmu Akuntansi, Keuangan dan Pajak, 4(1), 16-20.

\section{INTRODUCTION}

In the current era, the capital market is one means to get capital for companies for business activities in the capital. In the company's capital, one of which must go public. In addition, the capital market is an investment for capital owners and the wider community. These investments also need financial reports for reference or guidance on overall information from companies that go public (Oktarini and Wirakusuma, 2014). This financial report will be more useful if the reporting is timely. This time requirement is needed as information to make decisions. If the financial statements are not presented on time, then the accuracy of the information decreases in quality.

Companies that will report their financial reports have regulations regarding the timeliness stipulated in Law no. 8 of 1995 concerning Capital Markets. Bapepan also enclosed Decree of the Chairman of Bapepan-LK Number KEP - 346 / BL 2011, the Financial Services Authority (OJK) also issued a regulation, namely, regulation No XK2, Attachment No. Kep-431 / BL / 2012 
concerning Submission of Periodic Financial Statements of Issuers or Public Companies. In this regulation, every public company is required to submit the company's annual financial statements and independent audit reports to Bapepam no later than the end of the third month (90 days) after the date of the company's annual financial statements. In Indonesian Foam (BEI) also issued a decision of the directors No. 307 / BEJ / 2004, the regulation contains sanctions for companies that are late in submitting their reporting. Sanction I written warning if it is too late until the 30th day of submission of reporting limits. Then if the 31 st to 60 th days have not yet submitted their report, then they will be subject to written sanctions and a fine of 50 million. Until the 61st to 90th days, the company still has not submitted the written sanctions and a 150 million fine along with temporary termination by the Stock Exchange. Even though they have received sanctions and fines, sometimes, there are still companies that are late in submitting their financial statements. Then if the 31st to 60th days have not yet submitted their report, then they will be subject to written sanctions and a fine of 50 million. Until the 61st to 90th days, the company still has not submitted the written sanctions and a 150 million fine along with temporary termination by the Stock Exchange. Even though they have received sanctions and fines, sometimes, there are still companies that are late in submitting their financial statements. Then if the 31st to 60th days have not yet submitted their report, then they will be subject to written sanctions and a fine of 50 million. Until the 61st to 90th days, the company still has not submitted the written sanctions and a 150 million fine along with temporary termination by the Stock Exchange. Even though they have received sanctions and fines, sometimes, there are still companies that are late in submitting their financial statements.

Based on the IDX announcement in 2019, there were ten companies that were late in submitting their financial statements in 2018. In 2018 there were ten companies that were late in submitting their financial statements in 2017. In 2017 there were 17 companies that were late in submitting their financial statements in 2016. Company the late submission of its financial statements is because there are still problems in debt or the size of the company that is small so long. The factors that affect timeliness are companies that tend to get profits in submitting their reports on time and vice versa if the company suffers losses. That the company tends to forget the delivery of financial reporting if the company believes there is a crime, in the financial statements due to an influence on the quality of earnings. Company size also affects the timeliness measured in the size of the total assets or total sales owned by the company. Companies that have a large size then have better performance, management, and technology so that the delivery of reporting can be timely (Joened and Damayanthi, 2016)

Profitability has a positive effect on the timeliness of financial reporting, and this is because the profitability of a company is higher, the profit of the company also affects in terms of timeliness. The research is in line with research conducted (Putra and Ramantha, 2015), getting results in profitability, company age, and commissioners' independent positive effect on the timeliness of the publication of the annual financial statements. The size of the company studied by (Azhari and Nuryanto, 2019) get the results of profitability and company size has a positive effect on the timeliness of financial reporting, while institutional ownership and audit committee does not affect the timeliness of financial reporting, this is because the company is getting bigger and has a lot of accounting staff along with sophisticated information systems so that it can speed up the process of delivering financial statements. Several previous studies with the variable profitability and company size on timeliness. Namely, the research Liyundia Sayekti and Roziq (2017), Azhari and Nuryanto (2019), Putra and Ramantha (2015), Oktarini and Wirakusuma (2014), Joened and Damayanthi (2016) ), Sanjaya and Wirawati (2016).

\section{METHODS}

This research uses quantitative research methods by looking for associative relationships. This study analyzes and tests the theory of the value of research variables using statistical methods to 
determine the relationship between these variables - internal data used in the form of financial statements, historical data, and company summaries. External data sources come from prior research in the form of journals and theses with profitability variables, and company size. The population of this research is all manufacturing companies in the period of 2016 to 2018. Sampling uses purposive sampling so that the total sample of 115 companies is obtained. The determination of this research sample considers several criteria as follows: 1) The company that issues its complete report.

\section{RESULTS AND DISCUSSION}

Testing data normality using the Kolmogorov Smirnov test with residual data criteria is said to be normal if the significant value is above 0.05 or $5 \%$. Data normality test results using the Kolmogorov Smirnov test showed that a significant value of $0.139>0.05(5 \%)$, the data can meet the normality criteria so that the residual model is declared normal. In this study, a multicollinearity test was measured by fulfilling the criteria that the VIF value was not more than ten, and the tolerance value was more than 0.1 . VIF multicollinearity test results $\leq 10$ for all independent variables, also with a tolerance value $\geq 0.01$. Thus it can be concluded that there is multicollinearity between independent variables in the regression model. The test results show that the tolerance value of ROA is 0.960 , and the tolerance value of SIZE is 0.960. The VIF ROA value is 1.042, and the VIF Size value is 1.042. All variables used include ROA (profitability), and size (company size) have a tolerance value $\geq 0.1$, and a VIF value $\leq$ (Variance Inflation Factor) $\leq$ 10 means that both variables occur multicollinearity, which means that all of these variables cannot be used as mutually independent variables. Heteroscedasticity test results in the company sample showed the results of the sig value. 0,000 or greater than 0.05 , so it was decided that heteroscedasticity or data were said to have different variants. So that the model is not free from heteroscedasticity symptoms or data said to have the same variant (homoscedasticity). This study uses the Durbin Watson test criteria as an autocorrelation test method. The results of the autocorrelation test using the Durbin Watson test obtained Durbin Watson's value of 1.972. The criteria for testing autocorrelation in Durbin Watson's value of 1.972 lies between 1.55 to 2.46, which has the conclusion that the model does not experience autocorrelation symptoms or residuals do not have a correlation (correlation) with other observations arranged according to time series.

Multiple linear regression analysis is used in order to find out the formulation of the influence of the independent variables on the dependent variable. Based on the analysis results obtained formulation of multiple linear regression analysis models in this study as follows: $\mathrm{Y}=(1,614)+(-$ $0,035 \mathrm{X} 1)+-0.007 \mathrm{X} 2$. The constant value in the regression equation above is 1.614 , which means that if all independent variables are considered constant, it will cause a change in the timeliness of 1.614. The coefficient value of the independent ROA variable in the regression equation is -0.007 which means that if all independent variables are considered constant, it will cause changes to the timeliness of -0.007 The coefficient value of the variable size of the board of directors in the regression equation is -0.035 which means that if all independent variables are considered constant, it will cause a change in the timeliness of -0.035 .

Based on the results of the t-test (partial test), the $t$ value was calculated to have a negative direction of -2.877 . While the value of $\mathrm{t}$ table see the table of probability $\mathrm{t}$ or $\mathrm{df}=\mathrm{n} \mathrm{kl}$ or $\mathrm{df}=345$ $2-1=342$ with significance $\alpha=0.05$, it can be seen the value of $\mathrm{t}$ table $=1.966$. So the value of $\mathrm{t}$ count $<\mathrm{t}$ table or $-2.877<1.966$. The Sig value of the profitability variable in the table is 0.004 smaller than $\alpha=0.05$ or $0.004<0.05$, then $\mathrm{H} 1$ is accepted. The value of the positive t-test means that the variable $\mathrm{X} 1$ is not aligned with the variable $\mathrm{Y}$, so it can be concluded that profitability affects the timeliness. This profitability is the level of a company's ability to generate profits that will be reported and published. This profitability can affect the timeliness of reporting to the public 
(Azhari, and Nuryanto, 2019). Profitability is a company's success in making profits, so the higher the profitability, the higher the company's ability to generate profits for the company. This profitability is measured using Return On Assets (ROA), which is the ratio of net income after tax to the average total assets.

Based on the results of the t-test (partial test), the $t$ value was calculated to have a negative direction of $-3,556$. While the value of t table see the table of probability $t$ or $\mathrm{df}=\mathrm{nkl}$ or $\mathrm{df}=345$ $2-1=342$ with significance $\alpha=0.05$, it can be seen the value of $\mathrm{t}$ table $=1.966$. So the value of $\mathrm{t}$ count $<\mathrm{t}$ table or $-3.556<1.994$. The Sig value of the company size variable in the table that is 0,000 is smaller than $\alpha=0.05$ or $0,000<0.05$, then $\mathrm{H} 2$ is accepted. The value of the positive $\mathrm{t}$-test means that the variable $\mathrm{X} 2$ is not aligned with the variable $\mathrm{Y}$, so it can be concluded that company size affects the timeliness. In this company, size can show how much information contained therein, as well as reflecting management awareness about the importance of information, both for internal and external parties. Large companies have a broader base of interests so that various large policies will have a greater impact on the public interest (Sanjaya and Wirawati, 2016). The size of the company is a measure in which companies can be grouped according to various ways, including the total value of assets, total sales, market capitalization, number of workers, and so on. The coefficient of determination test aims to find out how much the model's ability to explain independent variations on dependent variations. The coefficient of determination test uses the value of $\mathrm{R}$ square (R2). The results of the coefficient of determination test on the value of $\mathrm{R}$ square (R2) of 0.071 or $7.1 \%$. This value shows that the timeliness is influenced by the level of profitability and size of the company $7.1 \%$, while the rest indicated by the value of $€ 92,9 \%$.

\section{CONCLUSION}

Vice versa, when profitability decreases and has a reporting time pattern exceeds the specified time limit, and it also affects investors in investing their shares in the company, and investor interest in the company decreases. 2) The size of the company (SIZE) affects the timeliness. Good company size or relative height of reporting company finances beyond the specified time period can be caused because when the company size is getting better or relatively high the company's financial reporting does not exceed the specified time period and can also influence investors towards the interest and partnership to invest in the company. Have a good company size, and While companies that have poor or declining company size tend to report company finances beyond the specified schedule, investors can also have an interest in and ownership to invest in these companies, which has a declining company size. Based on the results of the research that has been done, there are a number of suggestions in this study, among other things: 1). For researchers, setting a research sample should be broader, not limited to, manufacturing companies. 2). For further research, in formulating variables, it should be added so that more knowledge also gained in setting a research sample should be wider so that it is not limited to just one company.

\section{REFERENCE}

Azhari, F., \& Nuryatno, M. (2019). Opini Audit Pemoderasi Pengaruh Profitabilitas, Ukuran Perusahaan, Kepemilikan Institusional, Dan Komite Audit Terhadap Ketepatanwaktuan. Jurnal Ilmiah Akuntansi Dan Bisnis, 19-33. https://doi.org/10.24843/jiab.2019.v14.i01.p03

Baridwan, Z. (2010). Intermediate accounting. Yogyakarta: BPFE.

Bursa Efek Indonesia. 2015. Indonesia Stock Exchange Building. Jakarta

Rudangga, G. I., \& Sudiarta, G. M. (2016). Pengaruh Ukuran Perusahaan, Leverage, Dan Profitabilitas Terhadap Nilai Perusahaan. E-Jurnal Manajemen Universitas Udayana, 5(7).

Gunawan, I. (2017). METODE PENELITIAN KUANTITATIF. Teori dan Praktik Jakarta: PT Bumi Aksara. 
Umar, Husen. (2008). Metode Penelitian Bisnis Pendekatan Kuantitatif, Kualitatif, Kombinasi, dan R\&D. CV. ALFABETA. Bandung.

Ikatan Akuntan Indonesia. (2012). Standar akuntansi keuangan. Jakarta. SalembaEmpat.

Kurniawan, A. (2014). Metode Riset Untuk Ekonomi \& Bisnis, Penerbit Alfabeta, Bandung.

Liyundira, F. S. (2017). Dan tata kelola perusahaan. 528-539.

Made, N., Oktarini, L., \& Wirakusuma, M. G. (2014). Analisis Faktor-Faktor Yang Memengaruhi Ketidaktepatwaktuan Pelaporan Keuangan. E-Jurnal Akuntansi Universitas Udayana, 7(3), 648-662.

Paramita, R. W. D. (2014). Pengaruh Ketepatan Waktu Penyampaian Laporan Keuangan Terhadap Respon Laba Akuntansi. Jurnal WIGA, 4(2), 39-44.

Paramita, R. W. D., \& Rizal, Noviansyah. (2018). Metode Penelitian Kuantitatif Buku ajar Perkuliahan Metodologi Penelitian Bagi Mahasiswa. Azyan Mitra Media. Yogyakarta.

Paramitha, R. W. D. (2014). Timeliness Sebagai Variabel Intervening untuk Pengaruh Ukuran Perusahaan Terhadap Respon Laba. Jurnal WIGA, 4(1), 34-42.

Pramana, A., \& Ramantha, W. (2015). Pengaruh Profitabilitas, Umur Perusahaan, Kepemilikan Institusional, Komisaris Independen, Dan Komite Audit Pada Ketepatwaktuan Publikasi Laporan Keuangan Tahunan. E-Jurnal Akuntansi, 10(1), 199-213.

Prihadi, T. (2011). Praktis Memahami Laporan Keuangan sesuai IFRS dan PSAK. Jakarta: PPM Manajemen. Hal:164.

Sugiono. (2008). Metode Penelitian Kuantitatif, Kualitatif dan R\&D. Cv. ALFABETA. Bandung. Suryani \& Hendryadi. (2015). Metode Riset Kuantitatif : Teori dan Aplikasi pada www.idx.co.id 